\title{
DENDROECOLOGICAL ANALYSIS OF Ocotea pulchella AND Nectandra maegapotamica ON TWO SITES NEAR SANTA MARIA, RIO GRANDE DO SUL (BRAZIL)
}

\author{
Peter Spathelf ${ }^{1}$, Mário Tomazello Filho ${ }^{2}$, Helio Tonini ${ }^{3}$ \\ ${ }^{1}$ Eng. Florestal, Dr., Fachhochschule Eberswalde, Eberswalde, Germany - pspathelf@fh-eberswalde.de \\ ${ }^{2}$ Eng. Florestal, Dr., Depto. de Ciências Florestais, ESALQ/USP, Piracicaba, SP, Brazil - mtomazel@esalq.usp.br \\ ${ }^{3}$ Eng. Florestal, Dr., Centro de Pesquisa Agroflorestal, EMBRAPA Roraima, Boa Vista, RR, Brazil - helio@cpafrr.embrapa.br
}

Recebido para publicação: 24/10/2007 - Aceito para publicação: 25/03/2010

\begin{abstract}
A dendroecological analysis of Ocotea pulchella $(\mathrm{n}=5)$ and Nectandra megapotamica $(\mathrm{n}=2)$ was conducted on two sites near Santa Maria, Rio Grande do Sul (Brazil). Growth data were obtained by tree-ring analysis of stem disks at breast height $(1,3 \mathrm{~m})$. Radial increment was measured on four perpendicular radii using the 'LINTAB' measuring device. Mean growth sequences were standardised to highlight short-term variation. Air temperature, precipitation and compound climatic quantities like evapotranspiration and water balance were used to find indications about the climate-growth relationship. Variation of wood increment and climatic variation was compared by using sensitivity and correlation analysis. Some factors as regional climate (seasonality) in general, wood structure of the species and cross-dating of individual radii indicate that annual growth banding is likely. Due to a lacking correspondence between water balance and ring width indexes, water stress does not seem to be the synchronising factor of radial increment. In view of the measured periodical radial increments, it becomes evident that for Ocotea goal-diameters of 50-60 $\mathrm{cm}$ at breast height cannot be obtained in a short time without thinning. No medium-term growth release was found for both species.

Keywords: Dendroecology; annual rings; water balance; Ocotea pulchella; Nectandra megapotamica.
\end{abstract}

\section{Resumo}

Análise dendroecológica de Ocotea pulchella e Nectandra megapotamica em dois sítios próximos a Santa Maria, Rio Grande do Sul/Brasil. A análise dendroecológica de Ocotea pulchella $(\mathrm{n}=5)$ e Nectandra megapotamica $(\mathrm{n}=2)$ foi realizada em dois sítios próximos ao município de Santa Maria, RS/Brasil. Os dados de crescimento das 2 espécies foram obtidos através da análise dos anéis de crescimento de amostras do lenho da altura do DAP $(1,30 \mathrm{~m})$. Os incrementos radiais foram mensurados em 4 orientações radiais e perpendiculares, utilizando a mesa de mensuração 'LINTAB'. $\mathrm{O}$ histórico do crescimento médio em diâmetro do tronco das árvores foi estandardizado para a análise da variação de curto prazo. A temperatura do ar, precipitação e outros componentes climáticos (ex.: evapotranspiração, balanço de água) foram utilizados para analisar as correlações existentes com o crescimento das árvores. As variações do incremento radial e das variações climáticas foram comparadas utilizando-se a análise de sensitividade e de correlação. Alguns fatores climáticos sazonais regionais, a estrutura do lenho das espécies e a datação cruzada dos raios das amostras dos lenhos comprovam que os anéis de crescimento demarcam incrementos anuais. Devido à inexistência de relação entre o balanço de água e os índices de largura dos anéis de crescimento nas árvores das 2 espécies, o estresse hídrico não parece desempenhar um fator crítico de sincronização dos incrementos radiais do tronco.

Palavras-chave: Dendroecologia; anéis de crescimento anuais; balanço de água; Ocotea pulchella; Nectandra megapotamica.

\section{INTRODUCTION}

For a long time tree-ring analysis was scarcely applied in tropical forests due to the difficulties in finding distinctive annual growth rings. Today dendrochronologists are not so pessimistic about tropical tree-ring analysis. Some successful work has been done in the last decades. A good overview about 
examples of dendrochronological analyses in the tropics is given by Jacoby (1989), Worbes (1995), Stahle et al. (1999) or Roig (2000). Tomazello Filho et al. (2001) compiled the results of several dendroecological case studies in the tropics and subtropics concerning the tree family of the Meliaceae.

Air temperature in the tropics do not show a strong seasonality as in temperate climate zones. However, it is well known that in the tropics seasonality in precipitation (dry season) can also lead to cambial dormancy and the occurrence of increment zones (MEDINA, 1983; JACOBY, 1989; WORBES, 1995). At the higher latitudes of the subtropics a fairly strong seasonality in air temperature is common (JACOBY, 1989) and therefore, also in these regions tree-ring analysis basically is possible.

The methods proposed to prove whether tree rings in tropical species are annual in nature or not, have been widely applied with success and can be classified in non-destructive methods (like phenological observations or the application of dendrometer bands) and destructive methods (like cambial wounding, radiocarbon dating or the investigation of fire scars) (see WORBES, 1995).

The species under study Ocotea pulchella Nees et Mart. ex Nees (popularly known in South Brazil as canela-lageana) and Nectandra megapotamica (Spreng.) Mez. (popular: canela-preta) belong to the family of the Lauraceae (for a general description see MARCHIORI, 1997).

Ocotea pulchella and Nectandra megapotamica are evergreen species on the investigated sites. They extensively occur in the main phytogeographical formations of the state of Rio Grande do Sul, such as the Brazilian Pine Forest, Atlantic Rain Forest and deciduous forest of the upper Uruguay river (REITZ et al., 1988). They are shade-tolerant late successional species dominating in the upper storey of the stands. In Brazilian Pine stands at altitudes between 500 and $800 \mathrm{~m}$ asl they are also part of the understorey. According to Lorenzi (1992), both species grow on various types of soils.

In savanna formations both species only attain a few meters of height whereas in humid tropical forests specimen with $25-30 \mathrm{~m}$ of height and $50-80 \mathrm{~cm}$ of diameter can be found (RIZZINI, 1971). According to the same author, their wood is used for fences, posts and is considered to be a second class wood in the exterior civil construction.

In the present paper the wood formation of Ocotea pulchella and Nectandra megapotamica was studied on two sites in the state of Rio Grande do Sul, Southern Brazil, with special respect to annual growth rings. Moreover, growth was related to climate variables and possible medium-term growth alterations were investigated. It is expected that annuality of growth of the studied species can be proven by the applied technique, factors of water availability are the triggering factors for periodical wood growth, long-term growth patterns allow the derivation of management implications.

\section{MATERIAL AND METHODS}

\section{Study area}

- Site 1 (Ocotea pulchella, $\mathrm{n}=5$ ) is localised nearby Santa Maria, Rio Grande do Sul (Brazil), at the

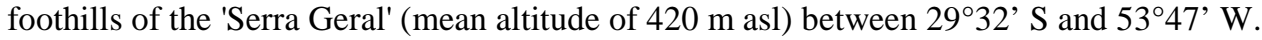

- The forests of site 1 can be described as an ecotone of the seasonal deciduous forest ('Floresta Estacional Decidual') with elements of the humid mixed forest ('Floresta Ombrófila Mista') like Araucaria angustifolia, Podocarpus lambertii and Blepharocalix salicifolia. Concerning the successional stage, the investigated stand represents a secondary forest. Natural regeneration and vertical structure is significantly harmed by cattle grazing. According to Brazil (1973), the soils are related to basaltic formations of the Serra Geral and can be classified as distrophic litosols. The sample area is localised at the border of a dam for water supply of the city of Santa Maria.

- Site 2 (Nectandra megapotamica, $\mathrm{n}=2$ ) is localised south-west of Santa Maria in the Central Depression of the state of Rio Grande do Sul at $29^{\circ} 47^{\prime} \mathrm{S}$ and $53^{\circ} 52^{\prime} \mathrm{W}$. Here forests only occur in the form of small patches ('capões'), that generally underlie strong human impact (fuelwood utilisation and cattle grazing). The natural forest vegetation is the seasonal deciduous forest ('Floresta Estacional Decidual'). The relief is plain to slightly undulated with altitudes varying from 60 to 125 $\mathrm{m}$ asl. At the lower altitudes the forest has the character of a gallery forest. The deeply developed red podzolic soils of the region originate from sandstone sediments (BRAZIL, 1973). 


\section{Climate}

At both sample sites climate can be described as typical Cfa type, according to Köppen's classification (MORENO, 1961). Mean annual precipitation (meteorological station of Santa Maria) between 1970 and 1996 was $1739 \mathrm{~mm}$ and mean annual air temperature $19,4{ }^{\circ} \mathrm{C}$ (Figure 1). In the observation period the mean air temperature of the coldest month (June) was $13,6{ }^{\circ} \mathrm{C}$ (but with absolute minimum temperatures of $-2,4{ }^{\circ} \mathrm{C}$ ), and the corresponding mean air temperature for the hottest month (January) was $25,0{ }^{\circ} \mathrm{C}$. The predominant winds were from west with a mean speed of $5,6 \mathrm{~km} / \mathrm{h}$.
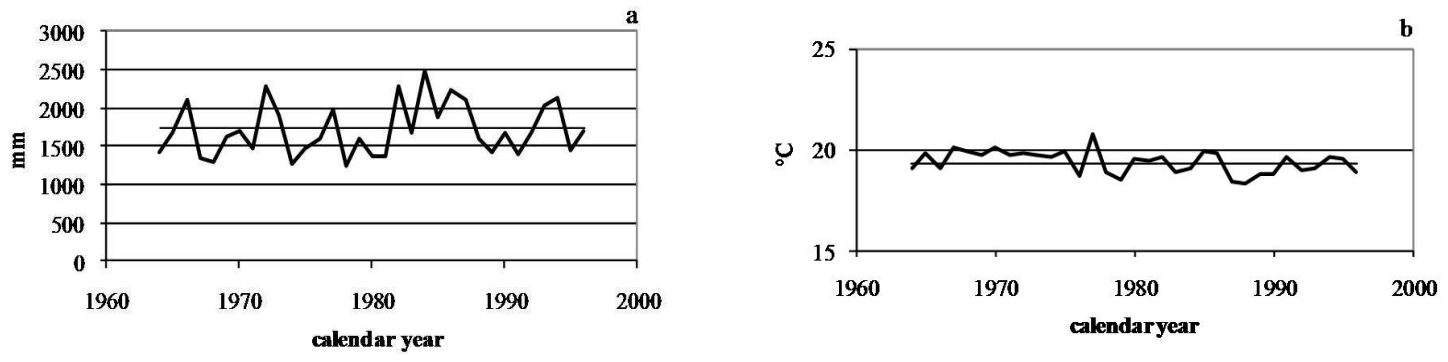

Figure 1. Variation of annual precipitation (a) and mean annual temperature (b) in Santa Maria (RS) in the period from 1970 to 1996.

Figura 1. Variação da precipitação anual (a) e da temperatura anual (b) em Santa Maria (RS) no período de 1970 até 1996.

\section{Data base}

To obtain the growth sequences, stem disks were cut at breast height, air-dried and sanded in order to turn the increment zones more visible. Four radii were marked on each of the stem disks by connecting the tree's pith with bark. The radii were traced with an angle of $90^{\circ}$ from each other beginning north. Then, increment zones were dated, starting with the last ring before sampling. Subsequently, the four radii were measured with an accuracy of $1 / 100 \mathrm{~mm}$ by using the 'LINTAB' measuring device (RINN, 1990). Mean monthly air temperature values and monthly precipitation from the meteorological station of Santa Maria, RS (measurement period of 1964 to 1996) served as the basis for compound climate-growth models.

\section{Data processing and modelling}

Cross-dating

Growth sequences from the stem disks were tested with the graphical tool of 'LINTAB' and with correlation analysis.

Pointer years

Pointer year detection was conducted using the interval trend method according to Schweingruber (1983). A pointer year was defined here to be a year when more than $90 \%$ of the trees showed a tendency of increase or decrease, in relation to the year before.

Medium-term growth changes

To determine medium-term growth changes the following calculation procedure was used:

$$
\text { (1) } \Delta_{(i)}=\left(i-\operatorname{lag}_{(i)}\right) / \operatorname{lag}_{(i)} * 100
$$

where: $\quad \Delta_{(\mathrm{i})}=$ percentile change of growth $(\%)$

$\mathrm{i}=$ increment $(\mathrm{mm})$

lag $=$ value of the year before 
A medium-term growth release is assumed when increment exceeds $\Delta_{(\mathrm{i})}$ of $30 \%$ during a period of at least five years (DEVALL et al., 1998).

\section{Sensitivity}

The sensitivity of growth response to environmental factors (e.g. climatic factors) was calculated by using the sensitivity concept of Schweingruber (1983). Sensitivity index is the quotient of annual sensitivity and the mean sensitivity of all trees of a site.

\section{Standardisation}

In order to relate tree increment with climate, increment sequences of the studied trees were standardised. To obtain the ring width index, annual increment values were divided through mean increment of the respective tree over the observation period. The resulting standardised procedure highlights the short-term variation of the sequence by eliminating long-term tendencies associated with the increasing size and age of a tree. Short-term variation is analysed in view of possible climatic signals. Finally mean curves (arithmetic mean) of all standardised tree-ring sequences of the two species were established, resulting in the corresponding standardised (final) tree-ring chronologies.

Climate variables

Air temperature, precipitation, evapotranspiration and water balance were considered as potentially influencing climate variables over growth. Evapotranspiration and water balance were calculated according to the method proposed by Thornthwaite; Mather (1957).

Correlation analysis

Correlation analysis was used to describe the relationship between growth and climatic variables. Moreover, also possible lag effects of climate variables on growth were taken into consideration.

\section{RESULTS AND DISCUSSION}

\section{Evidence of annual increment zones}

According to Stahle et al. (1999) the following four areas were analysed to obtain indications whether increment zones in the wood of Ocotea pulchella and Nectandra megapotamica are annual: phenology, ring anatomy, cross dating and the correlation between tree growth and climate data.

Phenology

The study region is characterised by a winter season with a period of low (or absent) cambial activity of the trees due to relatively cold temperatures (KLEIN, 1984). Both species are evergreen on the studied sites but a significant renewal of leafs occurs after flowering in October/November (Ocotea pulchella) and in December/January (Nectandra megapotamica) (REITZ et al, 1988, LORENZI, 1992, BRUN et al., 2000, submitted). Considering the regional climate conditions, a new growth period is induced by increasing temperatures at the end of the winter season. But also inherent factors of the species are likely to explain the seasonality of tree growth in South Brazil. Many of the deciduous tree species of South Brazil immigrated from the savanna ('Cerrado') with a severe dry period from May to September. Therefore, the above described phenological rhythm could also be genetically determined. These facts give a first indication about the possible annual nature of the increment zones of Ocotea pulchella and Nectandra megapotamica in the study region.

\section{Wood anatomy}

Both species, Ocotea pulchella and Nectandra megapotamica reveal distinctive increment zones. The boundaries are marked through an abrupt transition between the latewood (fibres with a shortened radial diameter and thickened walls) and the earlywood. However, wedging rings occur in both species. Moreover, density variations within increment zones are frequent, which are sometimes not easy to distinguish from ring boundaries. Number and size of vessels diminish from earlywood to latewood (see also INOUE et al., 1984, REITZ et al., 1988).

In general, wood anatomy of both species is quite similar. The main difference is the existence of paratracheal axial parenchyma in Nectandra megapotamica. 
Cross-dating

To support visual cross-dating of tree-ring sequences the standardised series were correlated among all trees at each site (Table 1). The time period for correlation analysis was 1960 to 1996. Significant correlations $(\mathrm{p}<0,05)$ at site 1 (Ocotea) were found between tree 1 and 2 , tree 1 and 3 , tree 2 and 3 , tree 2 and 5 and between tree 3 and 5. Tree 4 did not reveal any significant correlation with the other trees probably due to its inferior sociological position (suppressed tree).

Concerning site 2 (Nectandra) no significant correlations were found between the two sample trees. The degree of correspondence between the two mean index chronologies is not very strong $(\mathrm{r}=0,28$; $\mathrm{p}<0,0986)$.

Table 1. Pearson correlations (r) of standardised tree ring sequences between the sampled trees of Ocotea pulchella and Nectandra megapotamica (n.s. = not significant $\mathrm{p}<0,05)$.

Tabela 1. Correlação (Pearson) (r) das sequências estandardizadas de anéis de crecimento das árvores levantadas de Ocotea pulchella e Nectandra megapotamica (n.s. = não significante p<0,05).

\begin{tabular}{lcccccc}
\hline & & & & $\mathbf{r}$ & & \\
\hline Species & Tree number & $\mathbf{1}$ & $\mathbf{2}$ & $\mathbf{3}$ & $\mathbf{4}$ & $\mathbf{5}$ \\
\hline \multirow{2}{*}{ Ocotea pulchella } & 1 & - & 0,40 & 0,36 & n.s. & n.s. \\
& 2 & 0,40 & - & 0,73 & n.s. & 0,61 \\
& 3 & 0,36 & 0,73 & - & n.s. & 0,74 \\
Nectandra megapotamica & 4 & n.s. & n.s. & n.s. & - & n.s. \\
& 5 & n.s. & 0,61 & 0,74 & n.s. & - \\
\hline
\end{tabular}

Correlation between tree growth and climate

Standardised radial increments

Figure 2 shows individual radial increment sequences and the standardised mean radial increments (ring width indexes) of the studied species. In the case of Ocotea a period of relatively low growth in the 1960s is followed by an increase in the first half of the 1970s. Another increase occurs in 1988/89. Nectandra shows increased growth during 1972 to 1984, followed here by a sustained growth depression until the time of sampling.
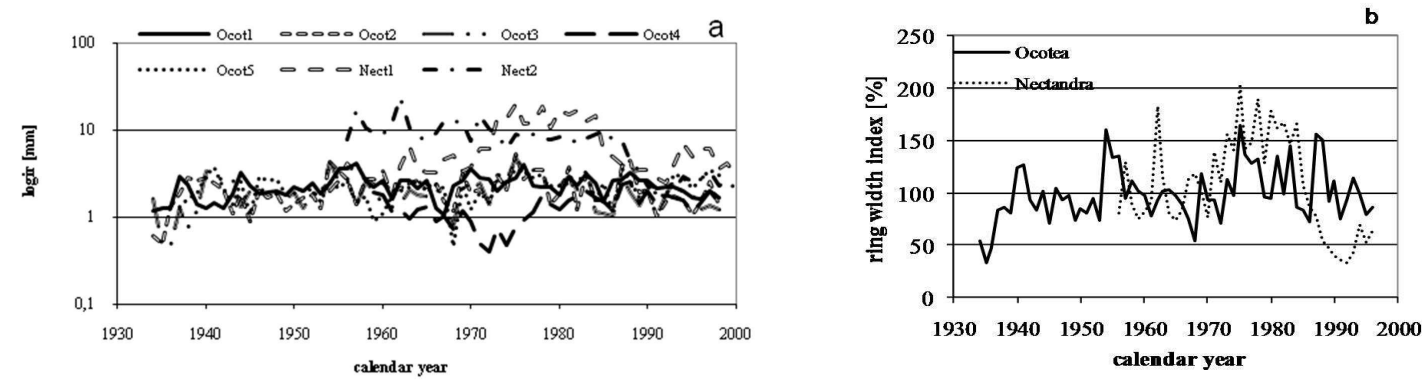

Figure 2. Individual radial increment sequences (a) and standardised tree-ring chronologies (b) of Ocotea pulchella $(\mathrm{n}=5)$ and Nectandra megapotamica $(\mathrm{n}=2)$.

Figura 2. Sequências do incremento radial (a) e cronologias estandardizadas (b) de Ocotea pulchella $(\mathrm{n}=5)$ e Nectandra megapotamica $(\mathrm{n}=2)$.

Pointer years and sensitivity

Sensitive growth responses in the 1970s until the early 1980s and in the beginning of the 1990s can be observed for both species (Figure 3). Conspicuous is the lack of sensitivity in the growth declining period of Nectandra within the second half of the 1980s. 

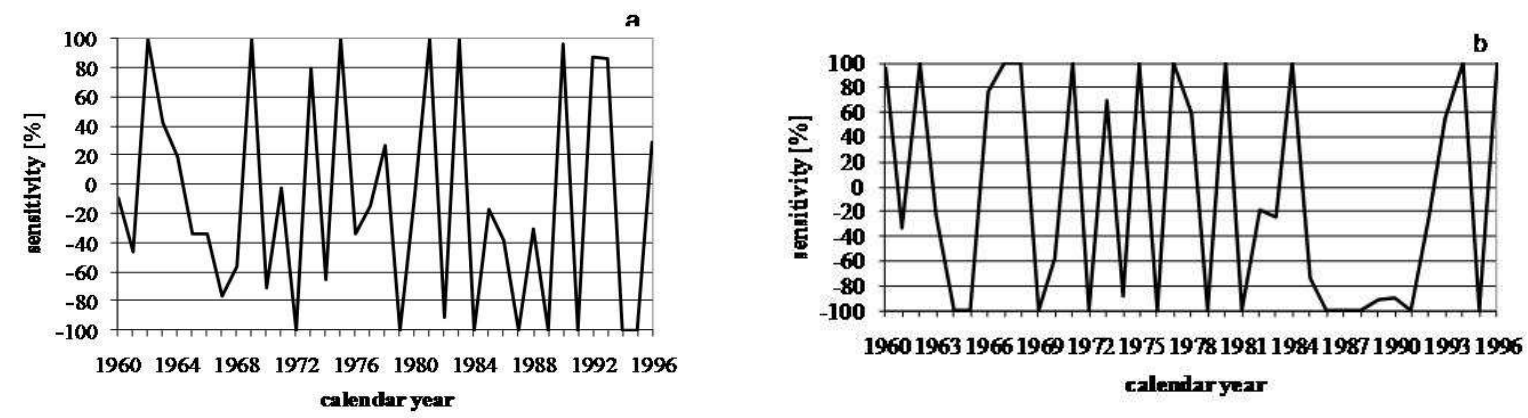

Figure 3. Sensitivity index for Ocotea pulchella (a) and Nectandra megapotamica (b).

Figura 3. Índice de sensitividade para Ocotea pulchella (a) e Nectandra megapotamica (b).

The results of pointer year analysis is shown in table 2. The pointer years are corresponding with the sensitivity pattern.

Table 2. Pointer years of the studied species according to the method of Schweingruber (1983).

Tabela 2. Anéis significados das espécies estudadas de acordo com o método de Schweingruber (1983).

\begin{tabular}{lcc}
\hline Species & Pointer years with low radial increment & $\begin{array}{c}\text { Pointer years with high radial } \\
\text { increment }\end{array}$ \\
\hline Ocotea pulchella & $1972,1979,1984,1989,1991,1994,1995$ & $1975,1981,1983,1987$ \\
\hline \multirow{2}{*}{ Nectandra megapotamica } & $1964,1965,1969,1972,1976,1979,1981$, & $1962,1967,1968,1971,1975,1977$, \\
$1986,1987,1988,1991,1995,1998,2000$ & $1980,1984,1994,1996,1999$ \\
\hline
\end{tabular}

Precipitation, air temperature and ring width index

No clear relationship was revealed between either precipitation or air temperature and ring width indexes of both species. The best but still weak correspondence was found with air temperature and the ring width index of Ocotea pulchella $(\mathrm{r}=-0,33 ; \mathrm{p}<0,0562)$. This could be an indication that growth is negatively influenced by increasing air temperatures (Figure 4).

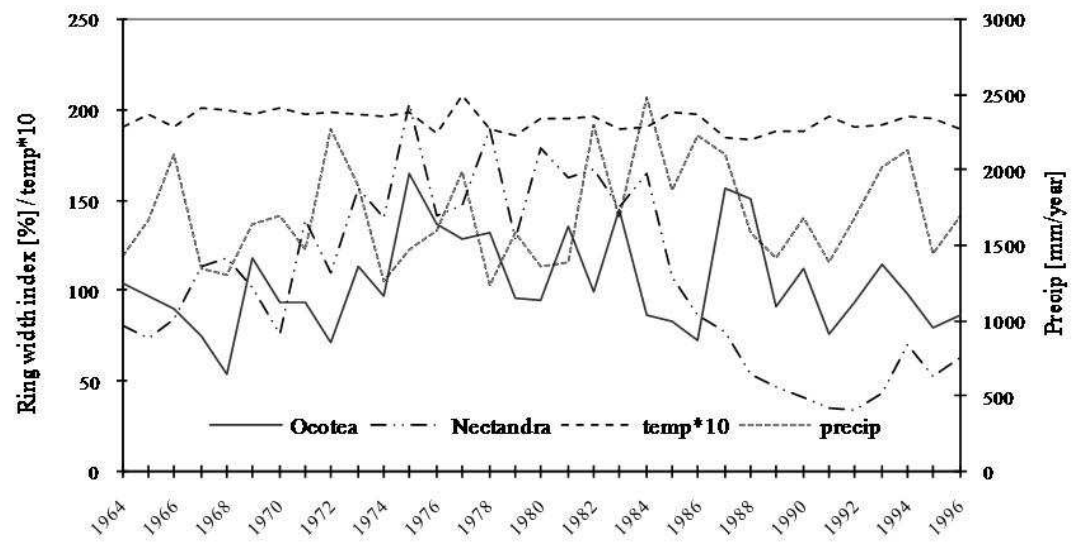

Figure 4. Ring width index, precipitation and temperature (temp*10) of Ocotea pulchella and Nectandra megapotamica.

Figura 4. Índice de largura de anéis, precipitação e temperatura (temp*10) de Ocotea pulchella e Nectandra megapotamica. 
Water balance and correlation analysis

The water balance, which was calculated for the period from 1970 to 1996 (data base: meteorological station of Santa Maria) only considers the growth period from October to April (Figure 5). A slight water balance deficit has to be stated for the years of 1974, 1975, 1978 and 1982. The long-term mean shows an excess of water of $28 \mathrm{~mm} /$ year.

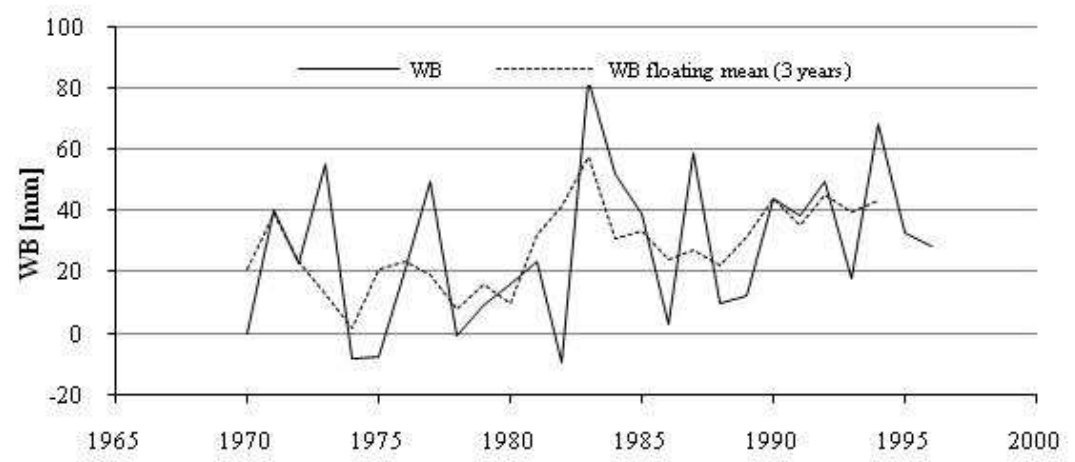

Figure 5. Water balance (WB) between 1970 and 1996 considering the growth period between October and April. Data from the metereological station of Santa Maria, rio Grande domSul (Brazil).

Figura 5. Balanço hídrico (WB) entre 1970 e 1996, considerando o period de outubro até abril. Dados são oriundos da estação mtereológica de /Santaa Maria, Rio Grande do Sul (Brasil)

If years with apparently low water balance (negative or around zero) during the growth period were analysed separately it can be shown that there are months with a high accumulated water balance deficit (Figure 6). Such a deficit can be observed from December to February in the year 1986. When years with water balance deficit are compared with pointer years with low radial increment (Table 2) it becomes evident that water balance deficit is not reflecting years with growth depression.

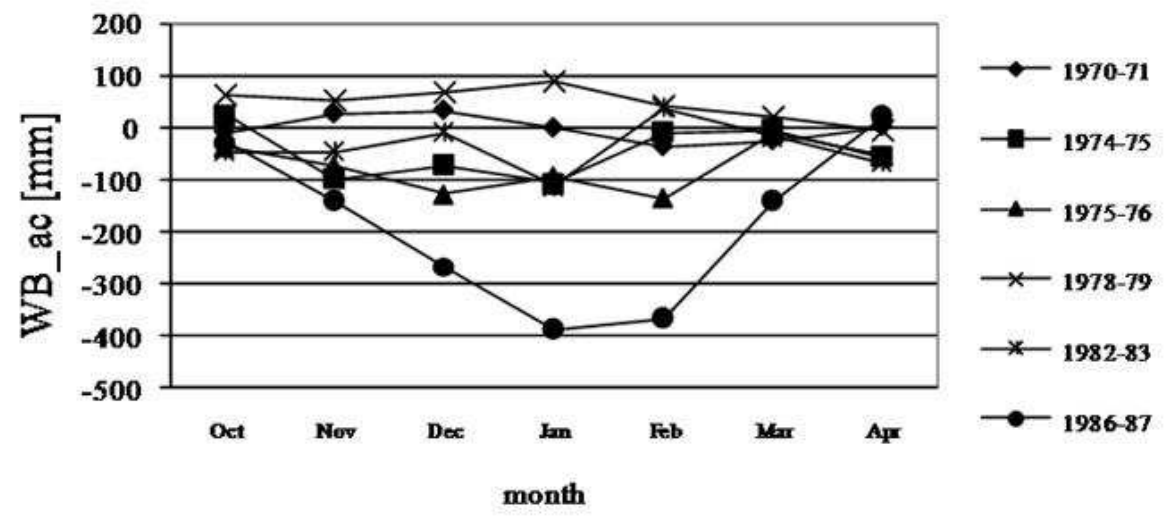

Figure 6. Accumulated water balance (WB_ac) during the growth period of years with low water supply. Figura 6. Balanço hídrico acumulado (WB_ac) durante o período de crescimento em anos com baixa disponibilidade de água. 
'Correlation analysis between ring width index, evapotranspiration and water balance of the respective year (lag 0 ) and the preceding year (lag 1) was conducted to reveal possible climate signals in the growth sequences, also considering a possible delaying effect of the tested variables. As shown in figure 7 climate variables are the mean values of the water balance (WB) and evapotranspiration (ETP) of the months November and December (legend: 1112), December and January (1201), January and February (0102) and February and March (0203).
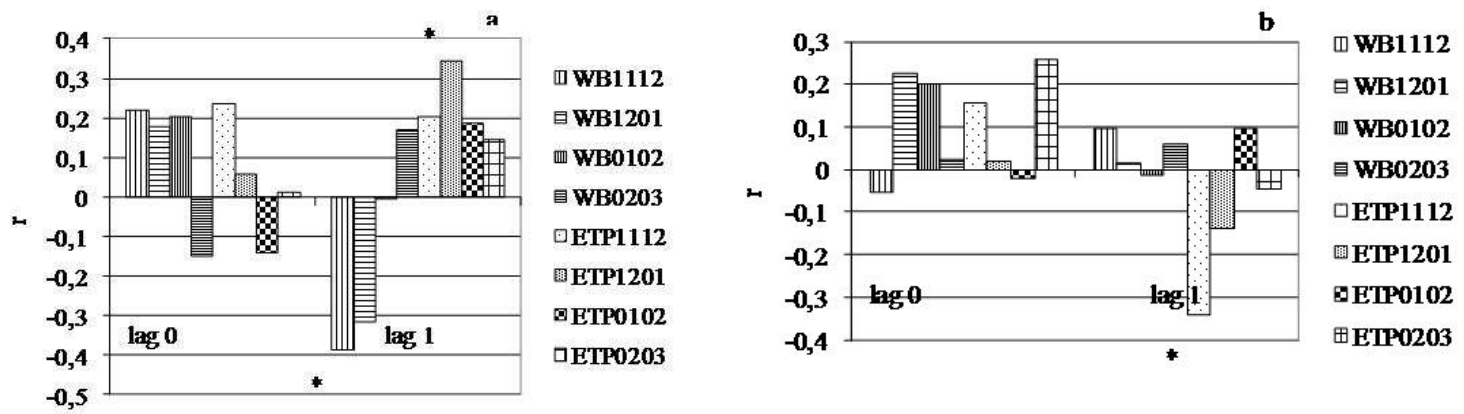

Figure 7. Correlations $(*=$ significant, $\mathrm{p}<0,05)$ between climatic variables and growth index of Ocotea pulchella (a) and Nectandra megapotamica (b) (WB: water balance; ETP: evapotranspiration; 1112: mean values of November and December; 1201: mean values of December and January; 0102: mean values of January and February; 0203: mean values of February and March).

Figura 7. Correlações $(*=$ significante, $\mathrm{p}<0,05)$ entre variáveis climáticas e índice de crescimento de Ocotea pulchella (a) e Nectandra megapotamica (b) (WB: balanço hídrico; ETP: evapotranspiração; 1112: valores médios de novembro e dezembro; 1201: valores médios de dezembro e janeiro; 0102: valores médios de janeiro e fevereiro; 0203: valores médios de fevereiro e março).

\section{Ocotea pulchella}

Through correlation analysis (Figure 7) it becomes evident that the WB between November and February is positively (but not significantly) correlated with growth of the current year (lag 0). It can also be shown that growth is positively influenced by the WB of February and March of the precedent year. Nevertheless a high WB in the months of November to January reduces growth of the following period (significant $[p<0,05]$ in the case of WB1112). The analysis of ETP suggests that high ETP in November, December and January stimulates growth in the same year. High ETP from January on, however, reduces growth. High ETP between November and March of the precedent year is positively correlated with diameter increment in the current year (significantly in the case of ETP1201).

\section{Nectandra megapotamica}

The correlation pattern of Nectandra is quite different compared to that of Ocotea. Positive correlation of WB with growth can be observed from December to March. ETP of November/December and February/March also positively influences growth in the same year. Moreover, ETP1112 of the precedent year has a (significant) negative effect on growth of the current year.

The results obtained by the climate-growth analysis allow to state that only a weak relationship exists between water supply and diameter increment of the current year. However, no coherent influence pattern of climate variables of the precedent year on current growth is visible.

\section{Cumulative diameter growth}

Diameter at breast height, age and mean annual diameter increment of the sample trees are shown in table 3. Cumulative diameter growth in function of age is shown in figure 8 .

The trees 1,2,3, and 5 of Ocotea have similar growth tendencies, attaining diameters at breast height from 26,0 to $29,9 \mathrm{~cm}$ in 62 and 65 years, respectively. This represents a mean annual increment of about $4,4 \mathrm{~mm}$. Growth is relatively constant over the whole growth period. Tree number 4 does not belong to the upper storey, showing a lower mean annual diameter growth of 2,8 $\mathrm{mm}$ (Figure 8). Probably 
due to severe competition beginning in 1971 (age of the tree at that time: 13 years) tree 4 lost its status as a canopy tree. Goal diameters of $30 \mathrm{~cm}$ and more at breast height only are obtained in periods of more than 60 years.

Table 3. Diameter at breast height, age and mean annual increment of the analysed trees.

Tabela 3. Diâmetro à altura do peito, idade e incremento médio anual das árvores analisadas.

\begin{tabular}{lcccc}
\hline Species & Tree number & $\begin{array}{c}\text { Diameter at breast height } \\
{[\mathbf{c m}]}\end{array}$ & $\begin{array}{c}\text { Age } \\
\text { [years] }\end{array}$ & $\begin{array}{c}\text { Mean annual } \\
\text { increment [cm/year] }\end{array}$ \\
\hline \multirow{3}{*}{ Ocotea pulchella } & 1 & 29,8 & 65 & 0,4583 \\
& 2 & 27,7 & 65 & 0,4266 \\
& 3 & 26,0 & 65 & 0.4002 \\
& 4 & 11,1 & 40 & 0,2785 \\
\multirow{2}{*}{ Nectandra megapotamica } & 5 & 28,2 & 62 & 0,4553 \\
\hline
\end{tabular}
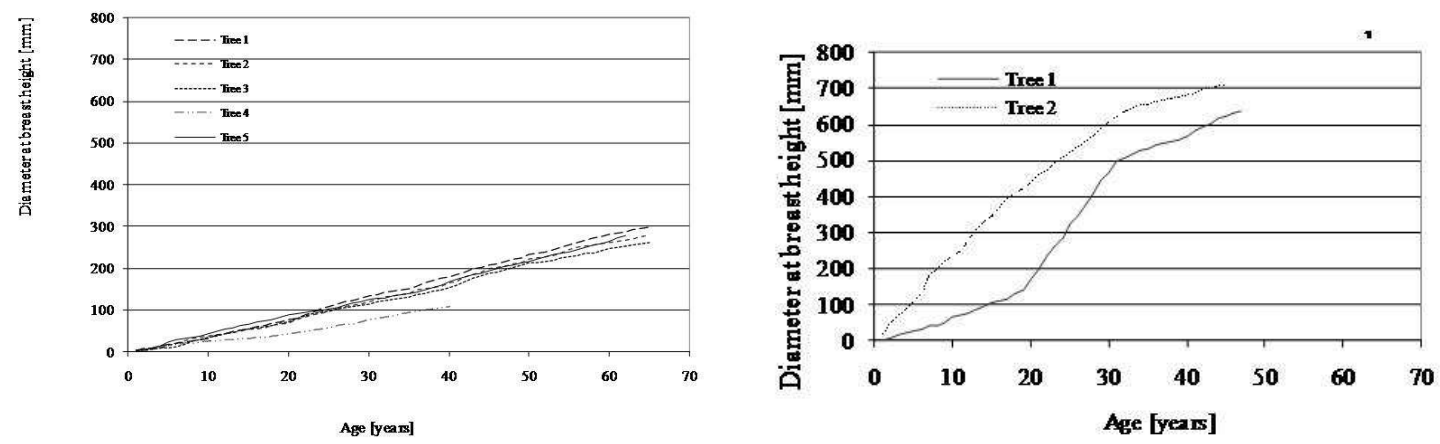

Figure 8. Diameter growth in function of age of Ocotea pulchella (a) and Nectandra megapotamica (b).

Figura 8. Crescimento em diâmetro em função da idade de Ocotea pulchella (a) e Nectandra megapotamica (b).

The growth in diameter of Nectandra is three times as high compared with Ocotea (Figure 8). Diameters at breast height of 63,7 and $70,9 \mathrm{~cm}$ were achieved at ages of 47 and 45 years, respectively. After an initial stage growth accelerates (more clearly with tree 1, where a diameter growth of $30 \mathrm{~cm}$ is achieved within the period between the age of 20 and 30 years), reaching a goal-diameter of $30 \mathrm{~cm}$ in 13 and 25 years, respectively. From the age of 30 years on, growth rate slightly decreases. But a levelling-off of diameter growth still is not visible at that age. This growth behaviour is comparable to the sigmoidal growth of trees in even-aged high forests (ASSMANN, 1970).

A comparison with other tree species from the study region reveals a more linear growth in comparison with Nectandra (Figure 9).

\section{Medium-term growth release} indexes.

In figure 10 the eight sample trees of the two species are shown with their respective ring width

No tree, either of Ocotea or of Nectandra reveals a growth release considering an increase of $30 \%$ for five consecutive years as defined in equation 1 (see section methods). Nevertheless, the growth index of Nectandra 1 is characterised by a clear positive shift in the early 1970s. This growth level is sustained for one decade, before it sharply decreases (Figure 10b). 


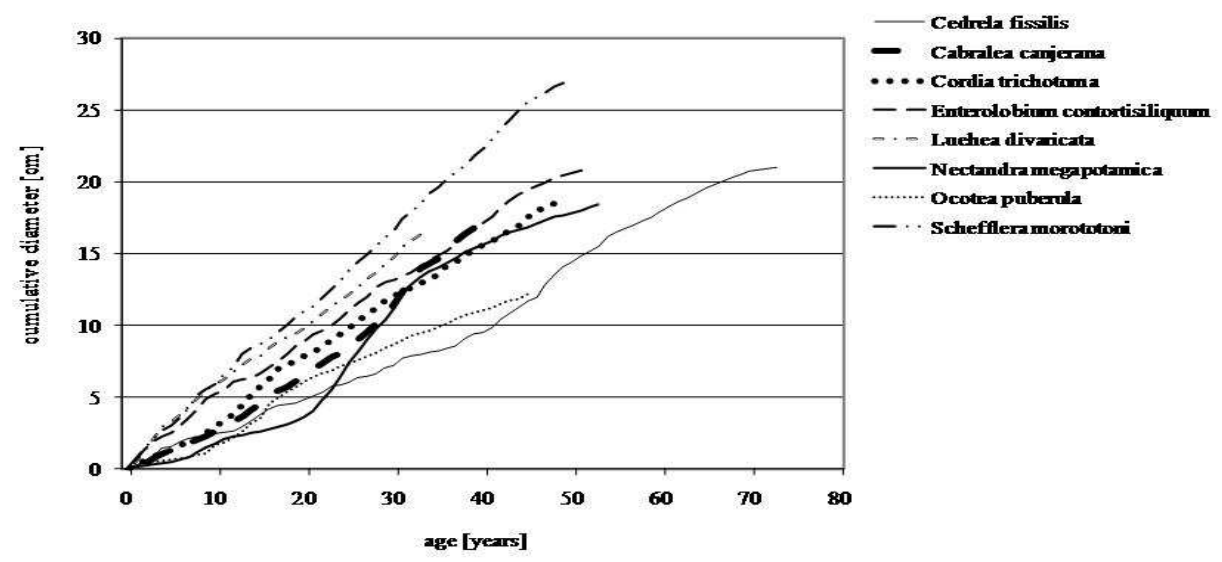

Figure 9. Cumulative diameter growth in function of age of other tree species of the study area.

Figura 9. Crescimento em diâmetro acumulado em função da idade de outras espécies na área de estudo.
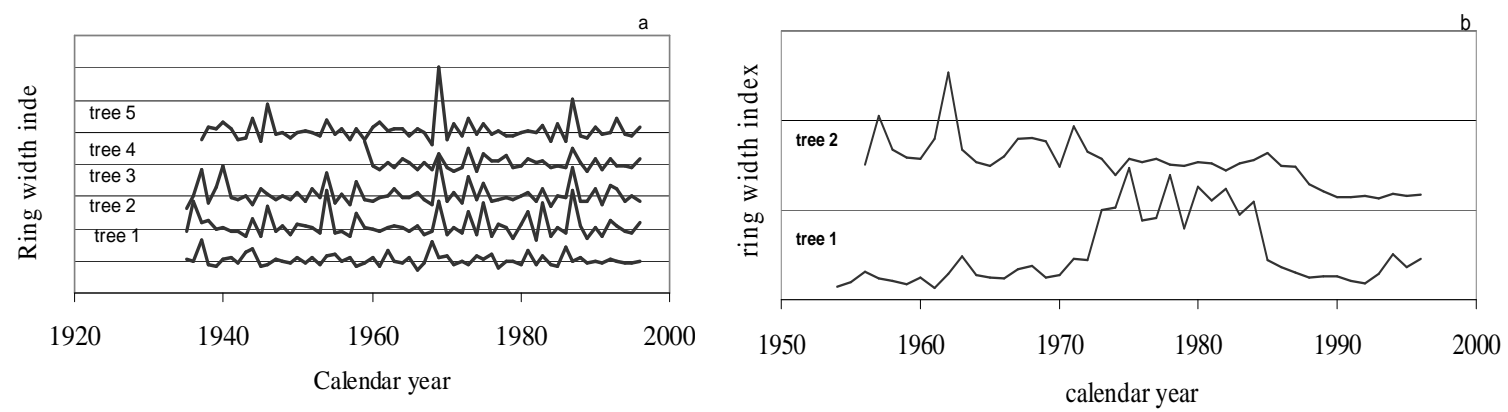

Figure 10. Percentile growth change of ring width index of Ocotea pulchella (a) and Nectandra megapotamica (b).

Figura 10. Mudança do crescimento em porcentagem do índice de largura dos anéis de Ocotea pulchella (a) e Nectandra megapotamica (b).

The growth sequences in figure 10 confirm the character of the sample trees as late successional species. These trees probably were capable to quickly occupy the standing space during the early stem exclusion phase and thus remained in the upper storey for a long time.

\section{CONCLUSIONS}

- From the present study it can be concluded that with the techniques applied, growth periodicity of the two species cannot be determined with absolute accuracy ( $\rightarrow$ hypothesis 1 ). Cambial wounding or radiocarbon-dating should be used to have a more precise answer (WORBES et al., 1995; WORBES; JUNK, 1989).

- Nevertheless, some factors as seasonality of air temperature, wood structure and cross-dating between different trees indicate that annual growth banding is likely. Water stress does not seem to be the triggering factor for periodical wood growth of the studied species, because no coherent pattern between water balance and ring width indexes was found ( $\rightarrow$ hypothesis 2 ).

- However, valuable management implications can be given on the base of the results of this study. E.g. by studying diameter growth tendencies, tree-ring analysis helps to set goal diameters and the time which is necessary to achieve them. Especially for Ocotea, it becomes evident that without 
thinning large goal-diameters of 50-60 $\mathrm{cm}$ at breast height cannot be obtained in a short time (e.g. within a felling cycle of 30 years) ( $\rightarrow$ hypothesis 3 ).

- Finally the approach of the present study allows to obtain an estimation of a species' long-term growth potential (senescence) and its capability of growth response due to environmental changes such as an abrupt increase of standing space ( $\rightarrow$ hypothesis 3 ).

\section{ACKNOWLEDGEMENTS}

We thank Mr. Solismar D. Prestes, head of the meteorological district of Porto Alegre, Brazil (INMET/MARA) for providing climatic data.

\section{REFERENCES}

ASSMANN, E. 1970. Principles of forest yield study. New York: Pergamon Press: 506 p.

BRASIL 1973. Ministério de Agricultura, Departamento Nacional de Pesquisa Agropecuária, Divisão de Pesquisa Pedológica. Levantamento de reconhecimento dos solos do Estado do Rio Grande do Sul. Recife: 430 p. (Boletim Técnico $\left.\mathrm{n}^{\circ} 30\right)$.

BRUN, E. J.; SCHUMACHER, M. V.; VACCARO, S.; SPATHELF, P. 2001. Relação entre a produção de serapilheira e variáveis climáticas em três fases sucessionais de uma floresta estacional decidual em Santa Tereza (RS). Revista Brasileira de Agrometeorologia, vol. 9, n. 2. p. 277-285.

DEVALL, M. S.; PARRESOL, B. R.; ARMESTO, J. J. 1998. Dendroecological analysis of a Fitzroya cupressoides and a Nothofagus nitida stand in the Cordillera Pelada, Chile. Forest Ecology and Management, 108: 135-145.

HUECK, K. 1966. Die Wälder Südamerikas: Ökologie, Zusammensetzung und wirtschaftliche Bedeutung. Jena: Fischer. 422 p.

INOUE, M. T.; RODERJAN, C. V.; KUNIYOSHI, Y. S. 1984. Projeto madeira do Paraná. Curitiba: Fundação de Pesquisas Florestais do Paraná, 260 p.

JACOBY, G. C. 1989. Overview of tree-ring analysis in tropical regions. IAWA Bulletin, 10: 99-108.

KLEIN, R. M. 1984. Síntese ecológica da floresta estacional da bacia do rio Jacuí e importância do reflorestamento com essências nativas (RS). In: Congresso Florestal Estadual, 5. 1984. Proceedings... Nova Prata: 265-278.

LORENZI, H. 1992. Árvores brasileiras: manual de identificação e cultivo de plantas arbóreas nativas do Brasil. Editora Plantarum, 352 p.

MARCHIORI, J. N. C. 1997. Dendrologia das Angiospermas: das Magnoliáceas às Flacurtiáceas. Santa Maria: Editora da UFSM, 271 p.

MEDINA, E. 1983. Adaptations of tropical trees to moisture stress. Ecosystems of the world, 14 A, 225237.

MORENO, J. A. 1961. Clima do Rio Grande do Sul. Porto Alegre: Secretaria da Agricultura, RS. 41 p.

REITZ, R.; KLEIN, R. M.; REIS, A. 1988. Projeto Madeira do Rio Grande do Sul. Porto Alegre: CORAG. 525 p.

RINN, F. 1990. TSAP/X: Computer program for dendrochronological databases, time series analysis and presentation graphics. Heidelberg.

RIZZINI, C. T. 1971. Árvores e madeiras úteis do Brasil: manual de dendrologia brasileira. São Paulo: Edgard Blücher. 294 p.

ROIG, F. A. 2000. Dendrocronologia en los bosques del Neotrópico: revisión y prospeccion futura. In: Roig, F. (ed.). Dendrocronologia en América Latina. Mendoza: EDIUNC. 307-355. 
SCHWEINGRUBER, F. H. 1983. Der Jahrring. Standort, Methodik, Zeit und Klima in der Dendrochronologie. Bern: Verlag Paul Haupt. 234 p.

STAHLE, D. W.; MUSHOVE, P. T.; ClEAVElAnD, M. K.; ROIG, F.; HAYNES, G. A. 1999. Management implications of annual growth rings in Pterocarpus angolensis from Zimbabwe. Forest Ecology and Management, 124: 217-229.

TOMAZELLO FILHO, M.; BOTOSSO, P. C.; LISI, C. S.; SPATHELF, P. 2001. Cedrela angustifolia Ses. et Moc. ex Dc., Meliaceae: potential species for tropical dendrochronology. Palaeobotanist, 50/1, p. 47-53.

THORNTHWAITE, C. W.; MATHER, J. R. 1957. Instructions and tables for computing potential evapotranspiration and the water balance. Drexel Institute of Technology - Laboratory of Climatology, 10, n. 3, Centeron, New Jersey. 308 p.

WORBES, M. 1995. How to measure growth dynamics in tropical trees - a review. IAWA Journal, vol. 16 (4): 337-351.

WORBES M.; JUNK, W. 1989. Dating tropical trees by means of 14C from bomb tests. Ecology, 70(2): 503-507. 